DOI: 10.26565/2312-5675-2021-17-08

UDC 316.613.43:17.036.2

\title{
THE INFLUENCE OF THE DIMENSIONS OF PERFECTIONISM ON THE FORMATION OF EMOTIONAL MALADJUSTMENT
}

\author{
M. Savina, M. Malakhovetska
}

Maiia V. Savina

*V. N. Karazin Kharkiv National University; Svobody Square, 6, 61022, Kharkiv, Ukraine

m.savina@karazin.ua

ORCID ID: 0000-0002-1292-7482

Mariia 0.Malakhovetska * mmalakhovetska@gmail.com

ORCID ID: 0000-0002-8066-4717

The growing complexity of the medical profession places increased demands on the future physician's adaptive capacity. The problem of the relationship of the affective spectrum disorders with such a dysfunctional personality trait as perfectionism is intensively discussed in clinical psychology. Medical students are in a more difficult position than others. It's related to their future profession requires a high level of training and also associated with a high responsibility for the lives and patient's health. High pace, intense workload, stress of life makes increased demands on the compensatory mechanisms of the medical student's psyche, failure of which leads to psychological and social conflicts.

The paper presents an empirical study of the severity of symptoms of depression, anxiety, and daily stress as the main components of emotional maladaptation, depending on the level of perfectionism in the medical student environment in conditions of increased psychological stress and pre-examination stress. Subjects with a low level of perfectionism are as emotionally prosperous as possible they have no signs of depression in $89 \%$ of cases. In the group of subjects with a medium level of perfectionism, the number of respondents in whom there are no signs of depression decreases and the number with mild, moderate and high levels of depression increases. In the group with a high level of perfectionism, the number of people without signs of depression is half of the whole group, a sharp increase in the number of subjects with moderate and high levels of depression. The level of depression in all three groups is statistically significantly different from each other: the lowest in the group with a low level of perfectionism and the highest in the group with a high level of perfectionism $(p<0.001)$. Positive correlations between the general indicator of perfectionism, its separate parameters and indicators of depression, anxiety and daily stress in the studied groups are revealed.

The data obtained as a result of the study confirm the high level of emotional maladaptation of medical students. In the academic student medical environment, respondents with a pronounced level of perfectionism experience more high-intensity, daily stress (both in the interpersonal and academic spheres of student life) compared to respondents with moderate and low levels of perfectionism.

Key words: emotional maladaptation, perfectionism, depression, anxiety, everyday stress.

Як цитувати: Савіна М. В., Малаховецька М. 0. The influence of the dimensions of perfectionism on the formation of emotional maladjustment // Психіатрія, неврологія та медична психологія. - 2021. - №17. - С. 61-67. https://doi.org/10.26565/2312-5675-2021-17-08

In cites: Savina M. V., Malakhovetska M. 0. The influence of the dimensions of perfectionism on the formation of emotional maladjustment. Psychiatry, Neurology and Medical Psychology. 2021. № 17, pp. 61-67.

https://doi.org/10.26565/2312-5675-2021-17-08 
The problem of students' emotional maladaptation is attracting more and more attention of specialists in various fields of medicine and psychology [1-3].

This problem of maladaptation is most relevant for mental health of various population groups especially medical students during the education. The increasing complexity of medical professions places greater demands on the adaptive capabilities of future doctors. Compared to students from other universities, medical students are in a more difficult situation, since their future profession requires not only a sufficiently high level of training, but also is associated with a high responsibility for the life and health of patients. The complexity of medical work is also due to the requirements of the continuity of the process of professionalization, the implementation of various structured activities, and manipulations. High pace, intensive training loads, life stress make high demands on the compensatory mechanisms of the psyche of medical students, the breakdown of which leads to the emergence of psychological and social conflicts [4-6]

According to some epidemiological data, affective disorders in the student population reach $20-30 \%$ of all respondents. Currently, in clinical psychology, the problem of the relationship between affective spectrum disorders and such a dysfunctional personality trait as perfectionism is being actively debated. The results of studies of the relationship between various parameters of perfectionism and emotional maladaptation among students indicate that high standards of activity, the absence of a subjective right to make mistakes, polarized thinking, constant comparison of oneself with others leads to the emergence of competitive relationships, social isolation and a lack of support [7-10]. This, in turn, leads to the experience of negative emotions, constant stress, depression, suicidal intentions and maladaptive avoidance behavior [11-13].

These circumstances significantly update the study of the relationship of the dysfunctional personality trait of "perfectionism» with symptoms of emotional distress.

The purpose of the research is to study the severity of symptoms of emotional maladaptation (depression, anxiety, and everyday stress) among medical students depending on the level of perfectionism.

Materials and methods. An empirical study was carried out on a sample of 144 medical students. Among them, 68 boys and 76 girls aged 18 to 22 years. To diagnose personal characteristics, a perfectionism questionnaire was used (N. G. Garanyan and A. B. Holmogorova) [14]. For diagnosing emotional maladaptation: Beck Anxiety Inventory (BAI), Beck Depression Inventory (BDI), Inventory of College Student's Recent Life Experiences (R. Kohn, J. Lafreniere, H. Gurevich, ICSRLE). Processing of the obtained results was carried out using the statistical software package SPSS 12.
The results of the study. The assessment of the overall level of perfectionism was carried out through the N. G. Perfectionism Questionnaire. Garanyan and A.B. Kholmogorova, who reveals five aspects of it, integrated into the total value of the trait [5]. As the average values of the perfectionism index, the data of T. Yu. Yudeeva obtained on a sample of healthy people $(M=47.7 ; S D=13.7)$. Indicators up to 33 points were considered low values of the severity of personality perfectional tendencies, medium values from 34 to 61 points, and high values over 62 points [5. S. 18].

As a result of the studies, all subjects were divided into 3 groups, respectively, with a low, medium and high level of perfectionism (Fig. 1.).

A comparative study of depression, anxiety and stress indicators was also conducted in students with various levels of perfectionism.

When comparing 3 groups in terms of depression, it was found that the group of subjects with a low level of perfectionism is as emotionally safe as possible (89\% have no signs of depression). In the group of subjects with an average level of perfectionism, the number of emotionally successful subjects (without signs of depression) decreases and the number with mild, moderate, and high levels of depression increases. In the group of subjects with a high level of perfectionism, the number of people without signs of depression is half the entire group; the number of subjects with moderate and high rates of depression increases sharply. The level of depression in all three groups is statistically significantly different from each other: the lowest in the group with a low level of perfectionism and the highest in the group with a high level of perfectionism ( $p<0.001$ ) (Fig. 2).

In terms of anxiety, a similar trend can be traced. In the group with a low level of perfectionism, the number of emotionally successful subjects is almost half. In the group of subjects with an average level of perfectionism, their number decreases, respectively, the number of people with signs of anxiety increases. In a group with a high level, the number of emotionally disadvantaged reaches its maximum. The difference in the level of anxiety in the group with a low and a high perfectionism index reaches statistical significance $(p=0.020)$ (Fig. 3).

Thus, in the group with a high level of perfectionism, the prevalence of emotional disorders in the form of symptoms of depression and anxiety is higher (at the level of statistical significance) than in the group with an average and low level of perfectionism.

When comparing 3 groups according to indicators of the general level of stress, it is important to note that in no group were subjects with a low level of stress (0-45).

It was found that the group of subjects with a low level of perfectionism is as safe as possible. In the group of subjects with an average level of perfectionism, the number 


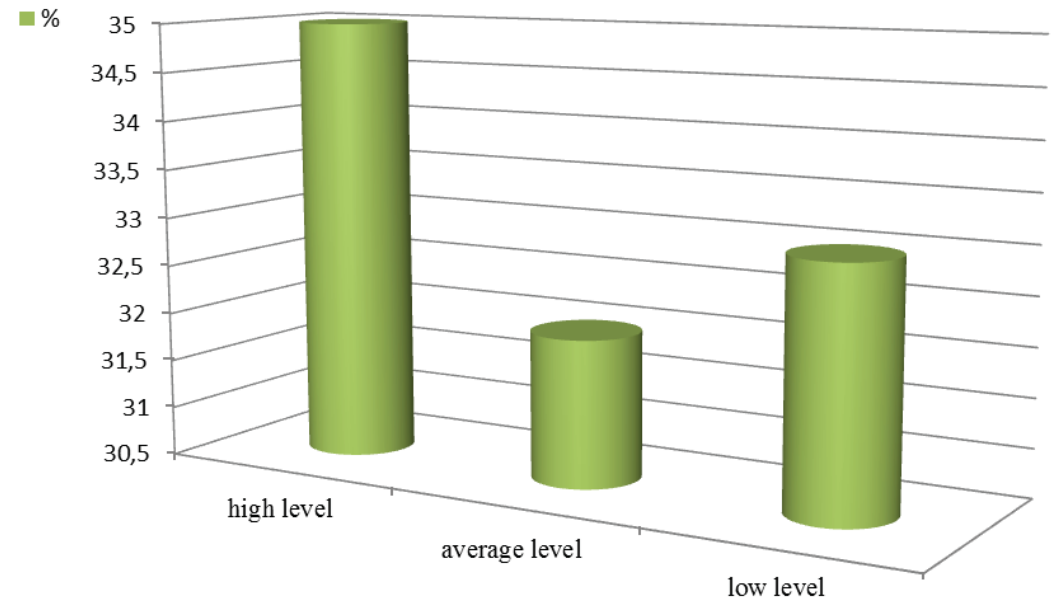

Fig. 1. Values of the general indicator of perfectionism in the experimental group

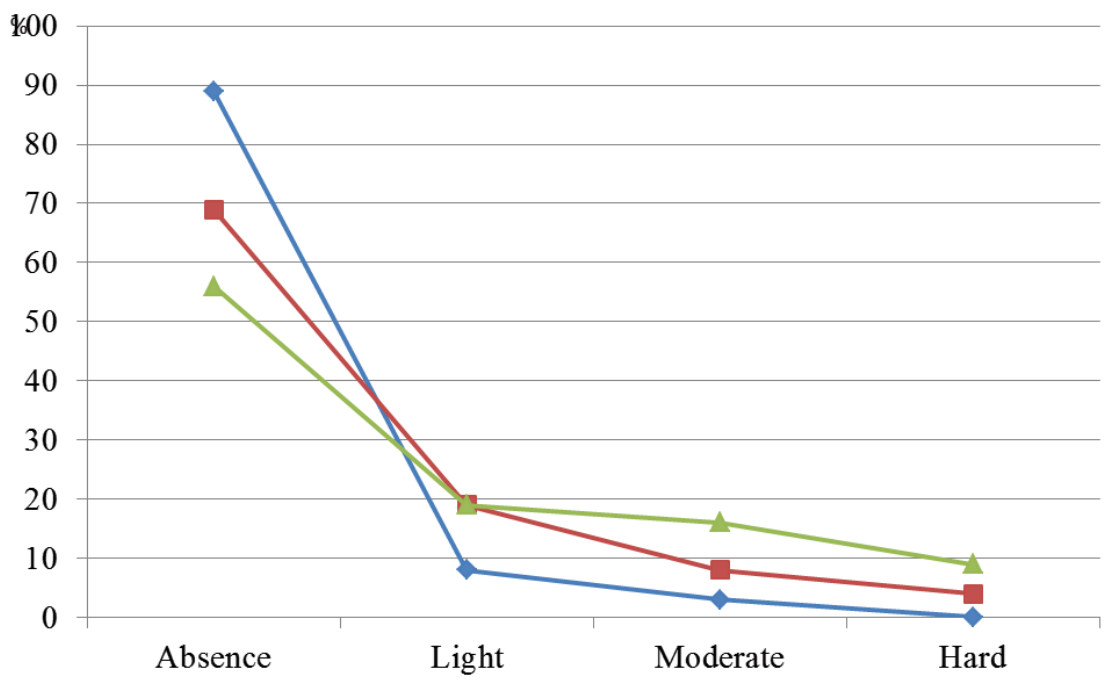

$\leadsto$ Low level of perfectionism

Average level of perfectionism

- High level of perfectionism

Fig. 2. Depression rates in subjects with different levels of perfectionism

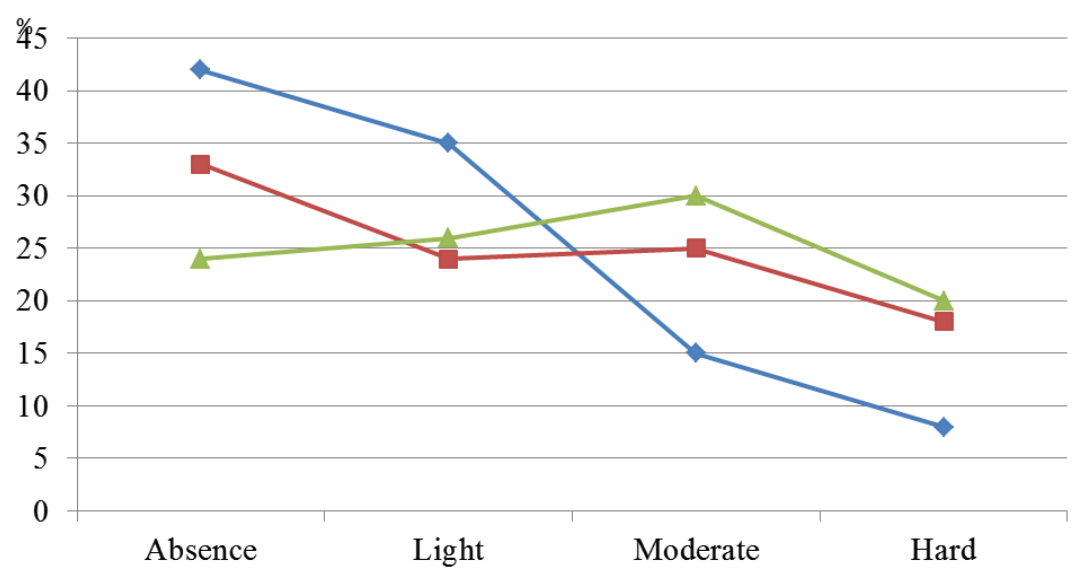

$\multimap$ Low level of perfectionism $\rightarrow$ Average level of perfectionism $\rightarrow$ High level of perfectionism

Fig. 3. Indicators of the level of anxiety in subjects with different levels of perfectionism 
of students with an average level of stress increases. In the group of subjects with high perfectionism, the number of people with moderate stress decreases, and with an average and high level of stress increases (Fig. 4,5).

In general, the average indicators of everyday stress are quite high among subjects (students) in all compared groups. They reach the maximum level in the group of subjects with a high level of perfectionism. Statistical analysis showed that students with high perfectionism had a significantly higher overall indicator of everyday stress compared with subjects with average perfectionism ( $p$ $<0.001)$ and subjects with low perfectionism $(p<0.001)$.

Subjects of the third group are also characterized by a significantly higher rate of interpersonal stress compared with subjects with average perfectionism $(p<0.001)$ and subjects with low perfectionism ( $p<0.001)$.

In the academic field, subjects with high perfectionism experience significantly more intense stress than students with an average level of perfectionism $(p=0.007)$ and a low level $(p<0.001)$. correlation analysis of the connection between perfectionism and such indicators of emotional maladaptation as anxiety, depression, and everyday stress (Fig. 6) was carried out.

As a result of the correlation analysis, numerous interconnections of individual parameters of perfectionism with symptoms of emotional maladaptation were established. So, the parameters "Perceiving others as delegating high expectations" and "Selecting information about failures and mistakes" correlate with all the symptoms of maladaptation: anxiety, depression and stress. The parameter "Excessive requirements for other people" correlates with stress indicators, both in the interpersonal and in the academic sphere. The parameters "High claims and requirements for oneself" and "High standards of activity" correlate with academic stress. And for the parameter "Polarized Thinking," no correlation with symptoms of emotional maladaptation was found. Beck's anxiety indicators correlate with perfectionism indicators such as Perception of Others as Delegating High Expectations and Selecting Information about Failures and

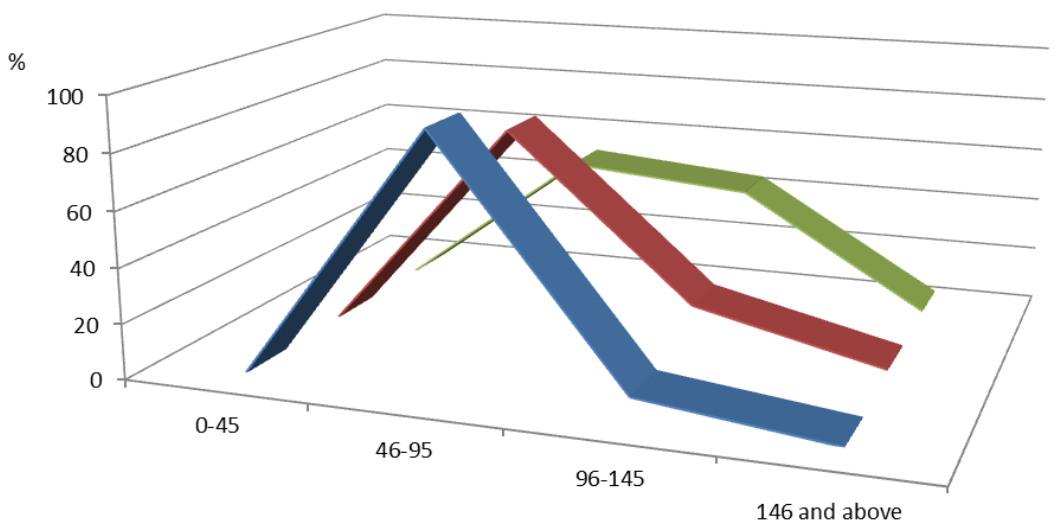

- Low level of perfectionism $\square$ Average level of perfectionism $\square$ High level of perfectionism

Fig. 4. Frequency indicators of stress in subjects with different levels of perfectionism

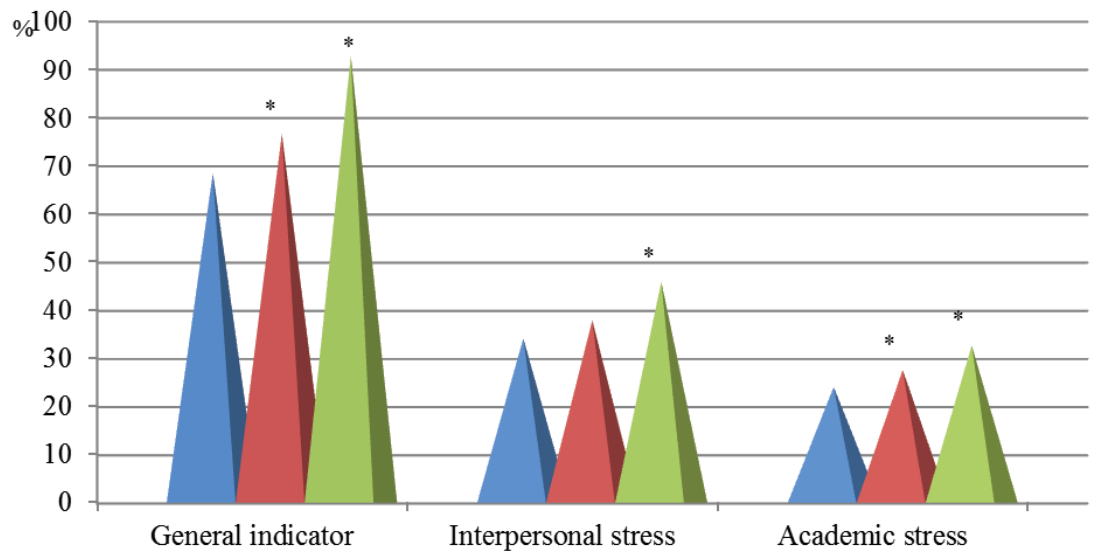

Low level of perfectionism

- Average level of perfectionism

High level of perfectionism

Fig. 5. Average values of daily stress in subjects with different levels of perfectionism 


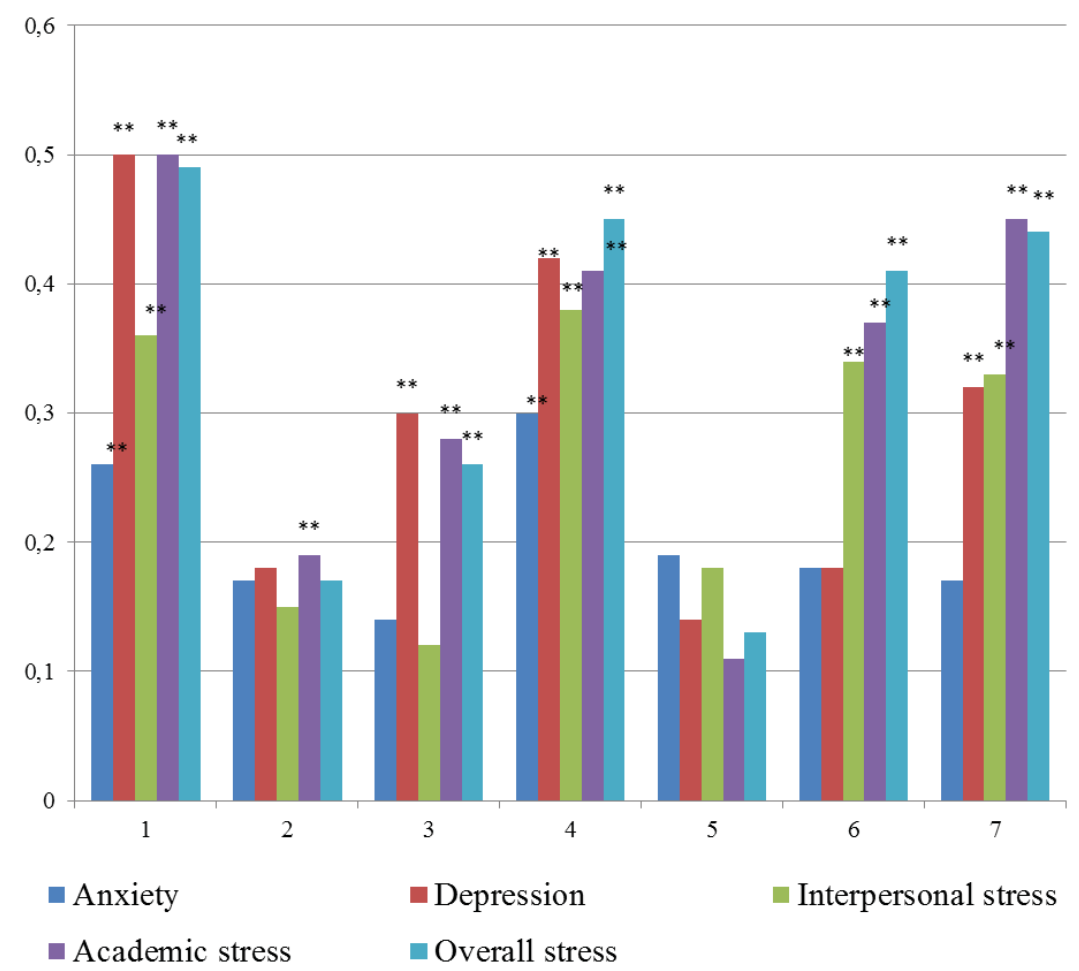

Fig. 6. Values of the correlation coefficient between indicators of anxiety, depression, stress and perfectionism

1. Perception of others as delegating high expectations

2. High claims and self-demands

3. High performance standards
4. Selecting failure and error information

5. Polarized thinking

6. Excessive requirements for other people
Errors. The indicators on the depression scale correlate with the general indicator for the perfectionism questionnaire, as well as with the factors "Perceiving others as delegating high expectations", "High standards of performance", "Selecting information about failures and mistakes".

The level of interpersonal stress correlates positively with the factors "Perceiving others as delegating high expectations", "Selecting information about failures and mistakes" and "Excessive requirements for other people", as well as with a general indicator of perfectionism. Indicators of academic stress are positively correlated with the factors "Perceiving others as delegating high expectations", "High standards of performance", "High claims and requirements for oneself", "Selecting information about failures and mistakes", "Excessive requirements for other people", and general indicator of perfectionism. The overall stress indicator is positively correlated with factors such as "Perception of others as delegating high expectations", "High standards of performance", "Selecting information about failures and mistakes", "Excessive requirements for others", and a general indicator of perfectionism.

Conclusions. Medical students are characterized by a high level of emotional maladaptation, manifested in symptoms of depression, anxiety, and intense everyday stress. Students with a high level of perfectionism (a dysfunctional personality trait that assumes excessively high requirements for self and performance) demonstrate significantly higher rates of emotional maladaptation compared to students with a moderate and low level of perfectionism. Positive correlations between the general indicator of perfectionism, its individual parameters and indicators of depression, anxiety and everyday stress were revealed.

\section{ЛІТЕРАТУРA}

1. (Mal)Adaptive Psychological Functioning of Students Utilizing University Counseling Services. / Biasi V., Cerutti R., Mallia L. та iн. // Front Psychol. - 2017. - №8. - C. 403. https://www.doi.org/10.3389/fpsyg.2017.00403

2. Byrd, D. R. Individual, interpersonal, and institutional level factors associated with the mental health of college students / Byrd, D. R., McKinney, K. J. // J. Am. Coll. Health. - 2012. - №60. - C. 185-193.

https://www.doi.org/10.1080/07448481.2011.584334
3. 0ostdam R.J. M. J. C. Maladaptive behavior in relation to the basic psychological needs of students in secondary educatio / Oostdam R. J. M. J. C., Koerhuis M. J. C., Fukkink R. G. // European Journal of Psychology of Education. - 2019. - №34. - C. https://www.doi.org/601-619.10.1007/s10212-018-0397-6

4. Хаустов М. М. Систематизація чинників ризику формування станів дезадаптації у студентів в сучасних умовах / Хаустов M. M. // Scientific journal «Science rise: medical science». - 2017. - №10. - C. 44-48.

https://www.doi.org/10.15587/2519-4798.2017.113511 
5. Barnett D. A. Grounded Theory for Identifying Students with Emotional Disturbance: Promising Practices for Assessment, Intervention, and Service Delivery. / Barnett D. A. // Contemporary School Psychology: Formerly «The California School Psychologist. - 2012. - № 16. - P. 21-31.

6. Sirota N. A. The Role of Emotional Schemas in Anxiety and Depression among Russian Medical Students. / Sirota N. A., Moskovchenko D. V., Yaltonsky V. M., Yaltonskaya A. V. // Psychology in Russia: State of the Art. - 2018. - Vol. 11(4). - P. 130-143.

https://www.doi.org/10.11621/pir.2018.0409

7. Гаранян Н. Г. Перфекционизм, депрессия и тревога / Гаранян Н. Г., Холмогорова А. Б., Юдеева Т. Ю.. // Московский психотерапевтический журнал. 2001. - №4. - C. 18-48.

8. Лоза 0. 0. Перфекціонізм студентської молоді: рівень вираженості та представленість у буденній свідомості. / Лоза 0. 0. // Вісник Дніпропетровського університету імені Альфреда Нобеля. Серія : Педагогіка і психологія. - 2014. - № 1. - С. 28-32.

9. Завада Т. Особливості взаємозв'язку перфекціонізму та самоактуалізації особистості. / Завада Т. // Вісник Київського національного університету імені Тараса Шевченка. Психологія. - 2014. - Вип. 2. - С. 31-34.
10. Hewitt P.L., Dyck D.G. Perfectionism, stress, and vulnerability to depression. / Hewitt P.L., Dyck D.G. // Cognitive Therapy and Research. - 1986. - №10. - C. 137-142.

11. Hewitt P., Flett G. Perfectionism and stress process in psychopathology. I Hewitt P., Flett G. // Perfectionism: Theory, research, and treatment. Washington. 2002. - P. 255-284.

https://www.doi.org/10.1037/10458-011

12. Hewitt P.L., Flett G.L. Dimensions of perfectionism, daily stress and depression: a test of specific vulnerability hypothesis. / Hewitt P., Flett G. // II Journal of abnormal psychology. - 1993. - Vol. 102(1). - P. 58-65.

13. Hamilton T., Schweitzer, R. The cost of being perfect : perfectionism and suicide ideation in university students. / Hewitt P., Flett G. // Australian and New Zealand Journal of Psychiatry. - 2000 - Vol. 34 (5). - P. 829-835.

https://www.doi.org/10.1080/j.1440-1614.2000.00801.x

14. Карамушка Л. М., Бондарчук 0. І., Грубі Т. В. Діагностика перфекціонізму та трудоголізму особистості : психологічний практикум. Кам'янець-Подільський : Медобори, 2018. 64 c.

\section{REFERENCES}

1. Biasi V., Cerutti R., Mallia L., Menozzi F. et al. (Mal)Adaptive Psychological Functioning of Students Utilizing University Counseling Services. Front Psychol. 2017. No. 8, p. 403.

https://www.doi.org/10.3389/fpsyg.2017.00403|

2. Byrd, D. R., and McKinney, K. J. Individual, interpersonal, and institutional level factors associated with the mental health of college students. J. Am. Coll. Health. 2012. №. 60, pp. 185-193.

https://www.doi.org/10.1080/07448481.2011.584334

3. Oostdam R. J. M. J. C. Koerhuis M. J. C., Fukkink R. G. Maladaptive behavior in relation to the basic psychological needs of students in secondary educatio. European Journal of Psychology of Education. 2019. №. 34, pp. 601-619.

https://www.doi.org/10.1007/s10212-018-0397-6.

4. Haustov M. M. Sistematizaciya chinnikiv riziku formuvannya staniv dezadaptaciï u studentiv v suchasnih umovah. Scientific journal «Science rise: medical science». 2017. №.10 (18), pp. 44-48. [in Ukr.]

https://www.doi.org/10.15587/2519-4798.2017.113511.

5. Barnett D. A Grounded Theory for Identifying Students with Emotional Disturbance: Promising Practices for Assessment, Intervention, and Service Delivery. Contemporary School Psychology: Formerly «The California School Psychologist. 2012. No. 16, pp. 21-31

6. Sirota N. A., Moskovchenko D. V., Yaltonsky V. M., Yaltonskaya A. V. The Role of Emotional Schemas in Anxiety and Depression among Russian Medical Students. Psychology in Russia: State of the Art. 2018. Vol. 11(4), pp. 130-143.

https://www.doi.org/10.11621/pir.2018.0409.
7. Garanyan N. G., Holmogorova A. B., YUdeeva T. YU. Perfekcionizm, depressiya i trevoga. Moskovskij psihoterapevticheskij zhurnal. 2001. No. 4, pp. 18-48. [in Russ.]

8. Loza 0. 0. Perfekcionizm students'koï molodi: riven' virazhenosti ta predstavlenist' u budennij svidomosti. Visnik Dnipropetrovs'kogo universitetu imeni Al'freda Nobelya. Seriya : Pedagogika i psihologiya. 2014. No. 1, pp. 28-32. [in Ukr.]

9. Zavada T. Osoblivosti vzaemozv'yazku perfekcionizmu ta samoaktualizaciï osobistosti. Visnik Kiïvs'kogo nacional'nogo universitetu imeni Tarasa Shevchenka. Psihologiya. 2014. No. 2, pp. 31-34.

10. Hewitt P.L., Dyck D.G. Perfectionism, stress, and vulnerability to depression. Cognitive Therapy and Research. 1986. №. 10, pp. 137-142.

11. Hewitt P., Flett G. Perfectionism and stress process in psychopathology. Perfectionism: Theory, research, and treatment. Washington, 2002, pp. 255-284.

https://www.doi.org/10.1037/10458-011.

12. Hewitt P.L., Flett G.L. Dimensions of perfectionism, daily stress and depression: a test of specific vulnerability hypothesis. II Journal of abnormal psychology. - 1993. Vol. 102(1), pp. 58-65.

13. Hamilton T., Schweitzer, R. The cost of being perfect : perfectionism and suicide ideation in university students. Australian and New Zealand Journal of Psychiatry. 2000. Vol. 34 (5), pp. 829-835.

https://www.doi.org/10.1080/j.1440-1614.2000.00801

14. Karamushka L. M., Bondarchuk 0. I., Grubi T. V. Diagnostika perfekcionizmu ta trudogolizmu osobistosti : psihologichnij praktikum. Kam'yanec'-Podil's'kij: Medobori, 2018. 64 p. [in Ukr.]

\section{ВПЛИВ РІВНІВ ПЕРФЕКЦІОНІЗМУ НА ФОРМУВАННЯ ЕМОЦІЙНОї ДЕЗАДАПТАЦІЇ}

\section{Савіна Майя Василівна}

\section{Малаховецька Марія Олександрівна*}

*Харківський національний університет імені В. Н. Каразіна, майдан Свободи, 6, 61022, м. Харків, Україна

m.savina@karazin.ua

ORCID ID: 0000-0002-1292-7482

mmalakhovetska@gmail.com

ORCID ID: 0000-0002-8066-4717 
пацієнтів. Високий темп, інтенсивні навчальні навантаження, напруженість життя пред'являють підвищені вимоги до компенсаторних механізмів психіки студентів медиків, зрив яких призводить до виникнення психологічних і соціальних конфліктів.

В роботі наведені дані емпіричного дослідження вивчення виразності симптомів депресії, тривоги, і повсякденного стресу, як основних складових емоційної дезадаптації, в залежності від рівня перфекціонізму в медичному студентському середовищі в умовах підвищених психологічних навантажень і передекзаменаційного стресу. Досліджувані з низьким рівнем перфекціонізму максимально емоційно благополучні — не мають ознак депресії в 89\% випадків. У групі досліджуваних з середнім рівнем перфекціонізму число респондентів, в яких відсутні ознаки депресії знижується і збільшується число з легким, помірним і високим рівнем депресії.У групі з високим рівнем перфекціонізму число осіб без ознак депресії становить половину всієї групи, різко зростає число досліджуваних з помірним і високим показниками депресії. Рівень депресії у всіх трьох групах статистично достовірно відрізняється один від одного: найнижчий в групі з низьким рівнем перфекціонізму і найбільш високий в групі з високим рівнем перфекціонізму ( $\mathrm{p}<0.001)$. Виявлено позитивні кореляційні зв'язки між загальним показником перфекціонізму, окремими його параметрами і показниками депресії, тривоги і повсякденного стресу в досліджуваних групах.

Отримані в результаті дослідження дані підтверджують високий рівень емоційної дезадаптації студентів медиків. В академічному студентському медичному середовищі респонденти з вираженим рівнем перфекціонізму відчувають більш восокоінтенсівний, щоденний стрес (як в інтерперсональній, так і в академічній сферах студентського життя) в порівнянні з респондентами з помірним і низьким рівнем перфекціонізму.

Ключові слова: емоційна дезадаптація, перфекиіонізм, депресія, тривога, повсякденний стрес.

\section{ВЛИЯНИЕ УРОВНЕЙ ПЕРФЕКЦИОНИЗМА НА ФОРМИРОВАНИЕ ЭМОЦИОНАЛЬНОЙ ДЕЗАДАПТАЦИИ}

\section{Савина Майя Васильевна}

*Харьковский национальный университет имени В. Н. Каразина, площадь Свободы, 6, 61022, г. Харьков, Украина

m.savina@karazin.ua

ORCID ID: 0000-0002-1292-7482

\author{
Малаховецкая \\ Мария Александровна*
}

mmalakhovetska@gmail.com

ORCID ID: 0000-0002-8066-4717

Возрастающая сложность медицинских профессий предъявляет повышенные требования к адаптационным возможностям будущих врачей. В клинической психологии интенсивно дискутируется проблема взаимосвязи расстройств аффективного спектра с такой дисфункциональной личностной чертой как перфекционизм. Студенты медики по сравнению со студентами других ВУЗов находятся в более сложном положении, так как их будущая профессия требует не только достаточно высокого уровня подготовки, но и связана с высокой ответственностью за жизнь и здоровье пациентов. Высокий темп, интенсивные учебные нагрузки, напряженность жизни предъявляют повышенные требования к компенсаторным механизмам психики студентов медиков, срыв которых приводит к возникновению психологических и социальных конфликтов.

Представлены данные эмпирического исследования изучения выраженности симптомов депрессии, тревоги, и повседневного стресса, как основных составляющих эмоциональной дезадаптации, в зависимости от уровня перфекционизма в медицинской студенческой среде в условиях повышенных психологических нагрузок и предэкзаменационного стресса. Испытуемые с низким уровнем перфекционизма максимально эмоционально благополучны — не имеют признаков депрессии в 89 \% случаев. В группе испытуемых со средним уровнем перфекционизма число респондентов не имеющих признаков депрессии снижается и увеличивается число с легким, умеренным и высоким уровнем депрессии. В группе испытуемых с высоким уровнем перфекционизма число лиц без признаков депрессии составляет половину всей группы, резко возрастает число испытуемых с умеренным и высоким показателями депрессии. Уровень депрессии во всех трех группах статистически достоверно отличается друг от друга: наиболее низкий в группе с низким уровнем перфекционизма и наиболее высокий в группе с высоким уровнем перфекционизма ( $\mathrm{p}<0,001)$. Выявлены положительные корреляционные связи между общим показателем перфекционизма, отдельными его параметрами и показателями депрессии, тревоги и повседневного стресса в исследуемых группах.

Полученные в результате исследования данные подтверждают высокий уровень эмоциональной дезадаптации студентов медиков. В академической студенческой медицинской среде респонденты с выраженным уровнем перфекционизма испытывают более восокоинтенсивный, ежедневный стресс (как в интерперсональной, так и в академической сферах студенческой жизни) в сравнении с респондентами с умеренным и низким уровнем перфекционизма.

Ключевые слова: эмоциональная дезадаптация, перфекционизм, депрессия, тревога, повседневный стресс. 